ACTA AGROBOTANICA

Vol. 62 (2): 3-12

2009

\title{
NECTARY STRUCTURE OF Ornithidium sophronitis RCHB.F. (ORCHIDACEAE: MAXILLARIINAE)
}

\author{
Małgorzata Stpiczyńska $^{1 *}$, Kevin L. Davies ${ }^{2}$ and Alan Gregg ${ }^{3}$ \\ ${ }^{1}$ Department of Botany, University of Life Sciences, Akademicka 15, 20-950 Lublin \\ University of Warsaw, Botanic Garden, Al. Ujazdowskie 4, 00-478 Warszawa, Poland \\ * For correspondence. E-mail malgorzata.stpiczynska@up.lublin.pl \\ ${ }^{2}$ School of Earth and Ocean Sciences, Cardiff University, Main Building, \\ Park Place, Cardiff CF10 3AT, UK \\ ${ }^{3}$ Swansea Botanical Complex, Singleton Park, Swansea SA2 9DU, UK
}

Received: 27.07.2009

\section{Abstract}

Most orchids do not produce floral food-rewards. Instead, they attract pollinators by mimicry or deceit. When present, the most common floral food-reward is nectar. To date, nectary structure has been described for only two species of Maxillaria sensu lato, namely Maxillariella anceps and Ornithidium coccineum (formerly Maxillaria anceps and M. coccinea, respectively). Here, we describe that of a third species, Ornithidium sophronitis (formerly Maxillaria sophronitis). This species possesses floral characters concomitant with ornithophily. A 'faucet and sink' arrangement is present, with nectar secreted by a protuberance on the ventral surface of the column, collecting between column and tepal bases.

The nectary of $O$. sophronitis shares many features with that of $O$. coccineum. It has a single-layered epidermis and 35 layers of small, subepidermal, collenchymatous, secretory cells. Beneath these occur 2-3 layers of larger, subsecretory, parenchymatous cells supplied by phloem. Nectary cell vacuoles contain osmiophilic material and proteinaceous intravacuolar bodies. Moreover, distension of the nectary cuticle occurs as nectar accumulates between it and the secretory epidermis. Subsecretory cells, however, have thinner walls and contain flocculent, intravacuolar precipitates that may be related to the presence of flavonoids.

Since the floral and nectary structure of $O$. sophronitis is very similar to that of closely related Ornithidium coccineum, it may have evolved in like manner in response to similar pollinator pressures.

Key words: labellum; nectary; cuticle; nectar; ornithophily; Maxillaria; Ornithidium

\section{INTRODUCTION}

Although many angiosperm families produce floral food-rewards, these are often absent from orchid flowers and here, pollinator attraction by mimicry and deceit tend to predominate ( $\mathrm{van} \mathrm{de} \mathrm{r} \mathrm{Pijl}$ and Dodson, 1969; A ckerman, 1984; van der C inge 1, 2001). However, rewards, when present in a flower, not only serve to attract potential pollinators, but also maintain a high incidence of pollinator visits and generally confer evolutionary advantage, in that they can double its chances of developing fruit and seed (Neiland and Wilcock, 1998). The most common food-reward in Orchidaceae is nectar ( $\mathrm{v}$ a n der Pijl and Dodson, 1969), and its presence significantly enhances the efficiency of pollination, as compared with other types of floral-food rewards or deceit alone (D a f n i and Iv ri, 1979; J o h n s o n and B o n d, 1997; N e i l a n d and W i l c o c k, 1998; Johnson and Nilsson, 1999; Neiland and $\mathrm{W}$ i l c o c k, 2000). However, the cost of nectar production and subsequent fruit and seed maturation can be great in terms of material and energy expenditure, and this may outweigh the benefits (Ackerman, Rodriguez-Robles and Meléndez, 1994; Meléndez-Ackerman, A ckerman and Rod rig u e z - R o b l e s, 2000, and references therein).

The Neotropical genus Maxillaria Ruiz and Pav., as traditionally defined, is thought to contain some 580 species and has long been considered to be an assemblage of morphologically disparate taxa (Whitten et al. 2007). Recent phylogenetic analyses indicate that Maxillaria is indeed grossly polyphyletic (B l a n c o et al. 2007, and references therein). As a result, B 1 a n c o et al. (2007) have proposed a new classification of core Maxillariinae that recognizes 17 genera (including $\mathrm{Or}$ nithidium Salisb. ex R. Br., Camaridium Lindl. and Maxillariella M.A. Blanco \& Carnevali). However, the proportion of Maxillaria (as previously circumscribed) that produces nectar is thought to be small and 
Davi es, S t pi c zy ńs ka and Gregg (2005) estimate it to be as little as $8 \%$. To date, our knowledge of nectary structure for Maxillaria is confined to just two species; Ornithidium coccineum (Jacq.) Salisb. ex R. Br. [formerly Maxillaria coccinea (Jacq.) L. O. Williams ex Hodge] and Maxillariella anceps (A mes \& C. Schweinf.) M. A. Blanco \& Carnevali [formerly Maxillaria anceps Ames \& C. Schweinf.]. In the first, a 'faucet and sink' arrangement is found, with nectar secreted by a protuberance on the ventral surface of the column collecting in a 'sink' formed by the proximal part of the labellum, the bases of the other tepals and the base of the column (S t piczyńs ka, D a vies and Gregg, 2004). In M. anceps, however, nectar produced by the callus is secreted onto the adaxial surface of the labellum by means of stomata ( $\mathrm{D}$ a vies, S t p i c z y ń s k a and Gregg, 2005).

The aim of the present paper is to describe the structure of the floral nectary of a third species formerly assigned to Maxillaria, namely Ornithidium sophronitis, and to compare it with that of closely related taxa.

\section{MATERIALS AND METHODS}

Nectary tissue of Ornithidium sophronitis Rchb.f. flowers was prepared and examined using light microscopy (LM), scanning electron microscopy (SEM) and transmission electron microscopy (TEM), as previously described (D a v i e s and S t p i c z y ń s k a , 2009). Also, as before, semi-thin sections were stained with toluidine blue $\mathrm{O}$ (TBO), and hand-cut sections of fresh material were tested for starch, as well as acidic polysaccharides and mucilage, using IKI and ruthenium red (J e n s e n , 1962), respectively.

Nectar-sugar concentration of fresh flowers was determined using refractometry and nectar tested for glucose using glucose-sensitive test sticks (Clinistix).

\section{RESULTS}

Flowers of $O$. sophronitis are weakly zygomorphic and diurnal. They lack fragrance and honey guides, but the yellow column and central area of the labellum contrast markedly with the other tepals, which are bright red in colour (Figs 1A-B). Cryptic, cream-coloured anther caps are present (Fig. 1B). The labellum is strongly folded (Fig. 1B) and copious floral nectar is produced.

Tepals of $O$. sophronitis are papillose and glisten (Fig. 1A). In section, these papillae are domeshaped, with a smooth, convex, outer tangential wall, lacking striations.

A small protuberance, some half way along the length of the ventral surface of the column, secretes nectar, and this collects between the column, the other tepals and the almost vertical, concave, proximal part of the relatively immobile labellum (Fig. 1B). Such is the volume of nectar produced, that it also often flows forward onto the mid-lobe of the labellum.

Refractometry of $O$. sophronitis nectar gave a value of $64 \%$ (w/w) sugar. Nectar was present in unopened buds of $O$. sophronitis and this, together with nectar tested 2-3 d into anthesis and again at late anthesis (close to senescence), was shown to contain glucose. Nectar was often produced in abundance, but at other times, none could be found.

The outer, tangential epidermal wall of the nectary has a thin, reticulate cuticle. SEM and TEM observations did not reveal ectodesmata, pores or cracks through which nectar could exude. However, characteristic, cuticular swellings (8-10 $\mu \mathrm{m}$ high) are present, and these usually occur at points coinciding with the middle lamella of radial walls between adjoining epidermal cells (Fig. 2A). These swellings occur exclusively on the surface of the nectary protuberance, being absent from neighbouring column cells (Fig. 2B).

The nectary consists of a single-layered epidermis and 3-5 layers of subepidermal, secretory cells (Figs 3A-C), beneath which occur 2-3 layers of subsecretory parenchymatous cells. Secretory cells are small $(17.5$ - $22.0 \mu \mathrm{m}$ diameter), whereas subsecretory parenchyma cells are larger (40.9 $\mu$ m mean diameter). Both secretory and subsecretory cells are compactly arranged. The nectary is supplied by phloem strands embedded in ground parenchyma directly beneath the subsecretory tissue (Fig. 3D). Staining with TBO revealed that the walls of secretory cells are cellulosic, whereas staining with ruthenium red revealed the presence of acidic polysaccharides in the middle lamella. A characteristic feature of these nectary cells is the presence of irregular, intravacuolar, protein bodies of variable size (Figs 3A, C, E). Starch was not detected in the plastids of nectary cells on treatment with IKI (Fig. 3B).

The secretory cells are collenchymatous (Figs $3 \mathrm{~A}-\mathrm{E}$ ), with relatively thick walls (mean $2.5 \mu \mathrm{m}$ ) containing numerous pits (Fig. 4C) and plasmodesmata (Fig. 4D). Nuclei were visible in the densely granular, parietal cytoplasm. The latter also contained numerous mitochondria, endoplasmic reticulum (ER) profiles, dictyosomes (Figs 4A-D) and darkly-stained, osmiophilic material (Figs 4A, C). Numerous, dilated vesicles frequently occurred in close proximity to the cell wall (Figs 4B-C). Plastids contained numerous, small plastoglobuli, but few lamellae. A granular, proteinaceous, intravacuolar body may be present (Fig. 3E) and this usually contains several globoids.

Subsecretory parenchyma cells (Figs 3A, C-D) have distinctly thinner walls (mean $0.5 \mu \mathrm{m}$ ) with abundant plasmodesmata. Few mitochondria are present 
and the cytoplasm contains starchless plastids, ER, and dictyosomes. Flocculent, intravacuolar precipitates may also be present (Fig. 3C), and these may be related to the presence of flavonoids.

\section{DISCUSSION}

It has long been speculated that $O$. sophronitis is ornithophilous. Unfortunately, direct evidence to support this has not been forthcoming. Recently, however, Whitten and co-workers (2007) have again asserted that the most brightly coloured Ornithidium species are probably hummingbird-pollinated, whereas those with more open, greenish flowers are probably bee- or wasp-pollinated.

Ornithophily has evolved many times (S pech t, 2006; Cronk and Oje d a, 2008), usually from entomophily. Bird-pollinated flowers are often red, pink, orange, yellow or white; less frequently, reddish-violet and blue (Proct or and Y e o, 1973; Ortega-Olivencia et al. 2005; Micheneau, F o urnel and Pailler, 2006). They exhibit diurnal anthesis, are weakly zygomorphic with a backwardly curved labellum that is strongly folded or has a substantial callus, thereby partially closing the floral tube at the level of the anther and stigma. They produce abundant nectar, but no fragrance, and they lack nectar guides. Floral tissues are often tough due to the presence of collenchyma (S t piczyńska, Davies and Gregg, 2004, 2005; S t piczyńska and $\mathrm{D}$ a vi e s, 2006) and can withstand contact with a hard beak (van der Pijl and D od s o n, 1969; van der $\mathrm{C}$ in g e 1, 2001). The presence of anther caps and pollinaria on beaks of birds usually evokes a bill-cleaning response and consequently, many pollinaria are either lost or destroyed. It is thus, perhaps, significant that some $50 \%$ of hummingbird-pollinated orchids have blue, grey, brown, cream or greyish-white, cryptic anther caps. These are thought to illicit a lesser response than more conspicuous, yellow anther caps and thereby facilitate pollination (D r e s s l e r, 1971). Flowers of $O$. sophronitis possess all these characters and are therefore, probably, bird-pollinated. Moreover, papillae on the adaxial tepal surface are smooth and convex, and the outer tangential wall lacks striations. The optical geometry of such cells is conducive to moderate surface reflection (Kay, D a o d and Stirton, 1981) and may account for the glistening appearance of the flowers. This, in turn, possibly helps to attract pollinators.

Orchid nectaries are generally thought to have perigonal origins ( $\mathrm{S}$ mets et al. 2000; R u dall, 2002; R u d 11 and B a te ma n, 2002) and are usually formed from the proximal part of labellum, or less frequently, from sepals (D re s s le r, 1993). Howev- er, in $O$. sophronitis, the nectary, like that of $O$. coccineum, is a small protuberance located on the column (Stpiczyńska et al. 2004) and thus, cannot be considered perigonal. In such 'faucet and sink' arrangements, nectar collects in a cavity formed by the proximal part of the labellum, the base of the column and the bases of the other tepals. Although not yet fully investigated, similar protuberances have been reported (S t p i c z y ńs k a et al. 2004) to occur in Maxillaria aggregata (H.B.K.) Lindl. (syn. Ornithidium aggregatum Rchb.f.), M. fulgens (Rchb.f.) L. O. Williams, M. nubigena (Rchb.f.) C. Schweinf. (syn. Ornithidium nubigenum Rchb.f.) and M. ruberrima (Lindl.) Garay (syn. Ornithidium ruberrimum (Lindl.) Rchb.f.). Rodrigo B. Singer (pers. comm., 2003) has also observed them in M. brevilabia Ames \& Correll (syn. Camaridium brevilabium (Ames \& Correll) M. A. Blanco), M. concavilabia Ames \& Correll and M. horichii Senghas (syn. Camaridium horichii (Senghas) M. A. Blanco). Remarkably, all these species have red, orange, pink or white flowers, or translucent flowers suffused with pink. However, Singer also reports a similar protuberance in $M$. parviflora (Poepp. \& Endl.) Garay. In this species, stingless bees (Meliponini), the typical pollinators of Maxillaria sensu lato, were observed feeding upon droplets of nectar that had collected in a 'conch-like cavity of the lip.' This is interesting, since the nectar-sugar concentrations of entomophilous Maxillariella anceps (D a v i e s et al. 2005) and presumed ornithophilous $O$. sophronitis are very similar $(66.5 \%$ and $64 \%(\mathrm{w} / \mathrm{w})$ sugar, respectively). Moreover, observation of cultivated $O$. sophronitis showed that, at intervals, nectar was produced in abundance, but that these episodes alternated with periods when no nectar could be found. This strongly indicates that floral nectar can be re-absorbed, as has also been recorded for a number of other orchid species (S t p i c z y ń s ka, 2003; Davies and Stpiczyńska, 2008, and references therein).

The nectary tissue of $O$. sophronitis shares a number of unusual features with other presumed ornithophilous species, such as $O$. coccinea and Hexisea imbricata (Lindl.) Rchb.f. (S t p i c z y ń s k a et al. 2004, 2005), in particular, the presence of collenchyma. It is thought that the thickened cell walls of this tissue probably provide an apoplastic route for nectar movement within the nectary, especially in the absence of cutinized layers and other barriers that could impede nectar flow, whilst simultaneously preventing damage caused by the beaks of visiting birds. However, the numerous plasmodesmata might indicate an additional symplastic route in this species, as has already been recorded for other taxa (F a h n , 2000; S t p i c z y ń s k a et al. 2004; N e p i , 2007). A second character shared with $O$. coccinea and $H$. imbricata is the presence of 

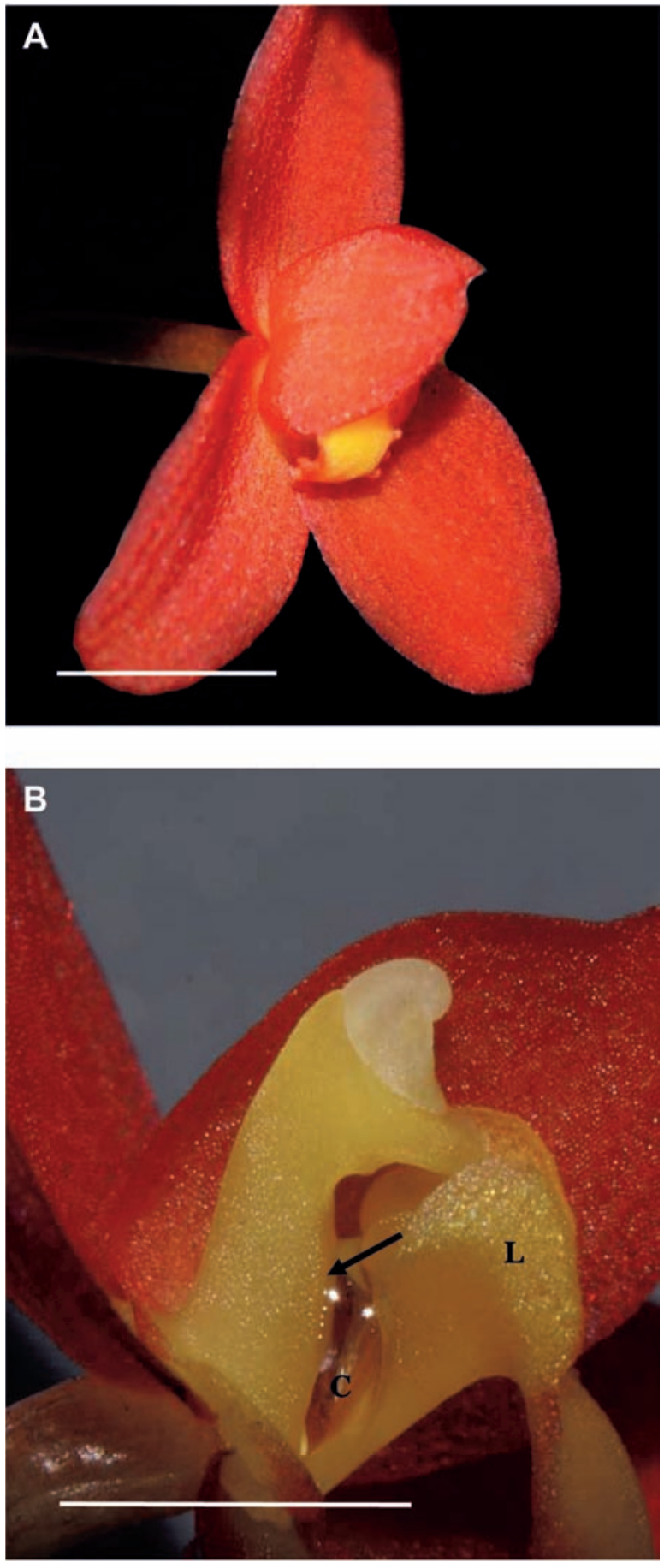

Figs 1A-B. Onithidium sophronitis (A) has weakly zygomorphic, bright red flowers with connivent petals and a yellow area upon the labellum. Note also that the tepals are papillose and glisten. Dissected flower of $O$. sophronitis (B) showing position of protuberant nectary (arrow) on ventral surface of column. Note also the cavity, the site of nectar accumulation, formed by the bases of column, tepals and strongly folded labellum, as well as the cream-coloured anther cap. Scale bars $=5 \mathrm{~mm}$, throughout. 

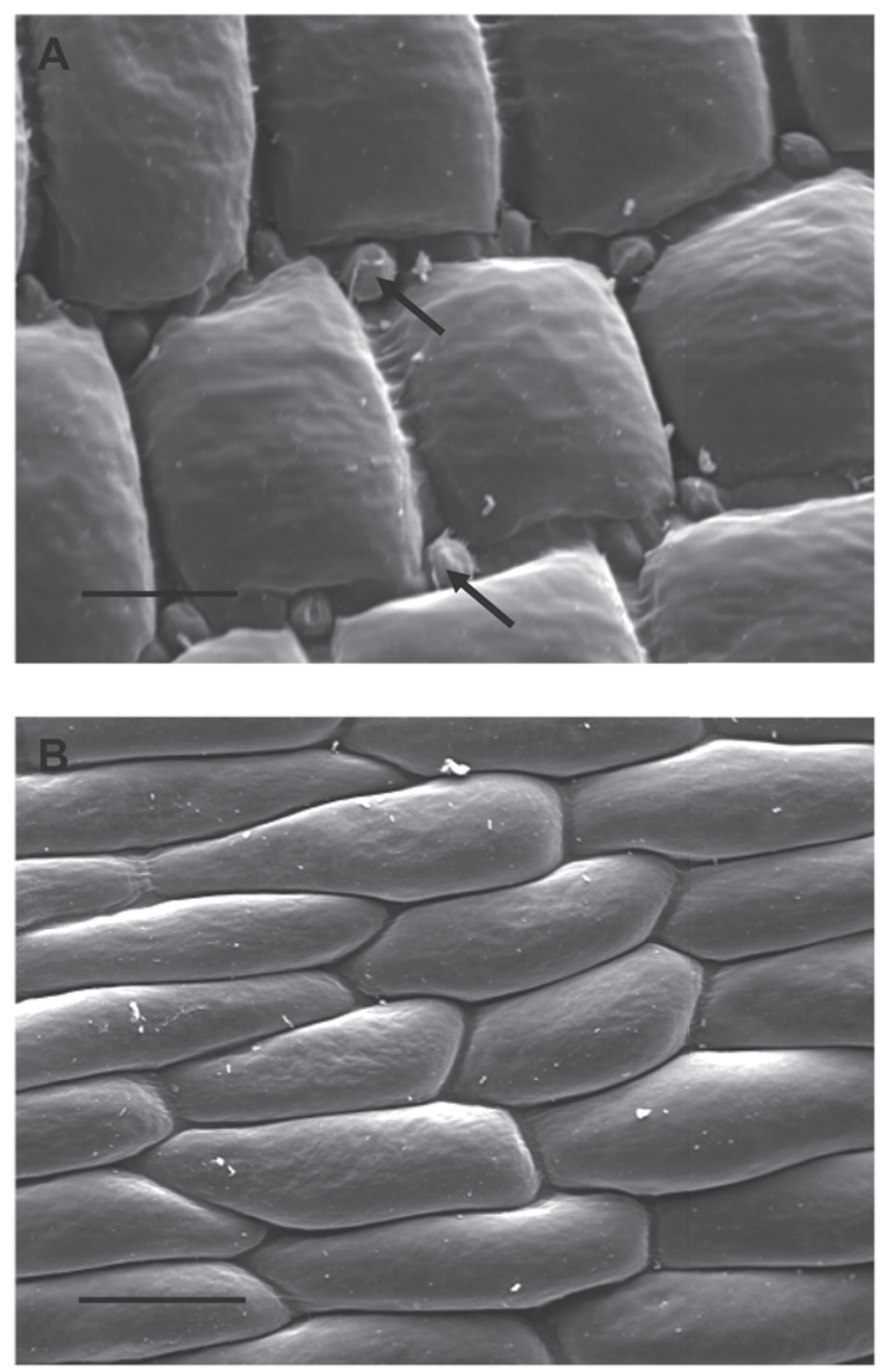

Figs 2A-B. Epidermal cells of $O$. sophronitis nectary (A) and adjacent region of column (B), respectively. Both have a thin, reticulate cuticle. However, small, spherical, cuticular swellings (arrows) occur between the epidermal cells of the nectary (A), whereas these are absent elsewhere on the column (B). Scale bars $=10,40 \mu \mathrm{m}$, respectively. 

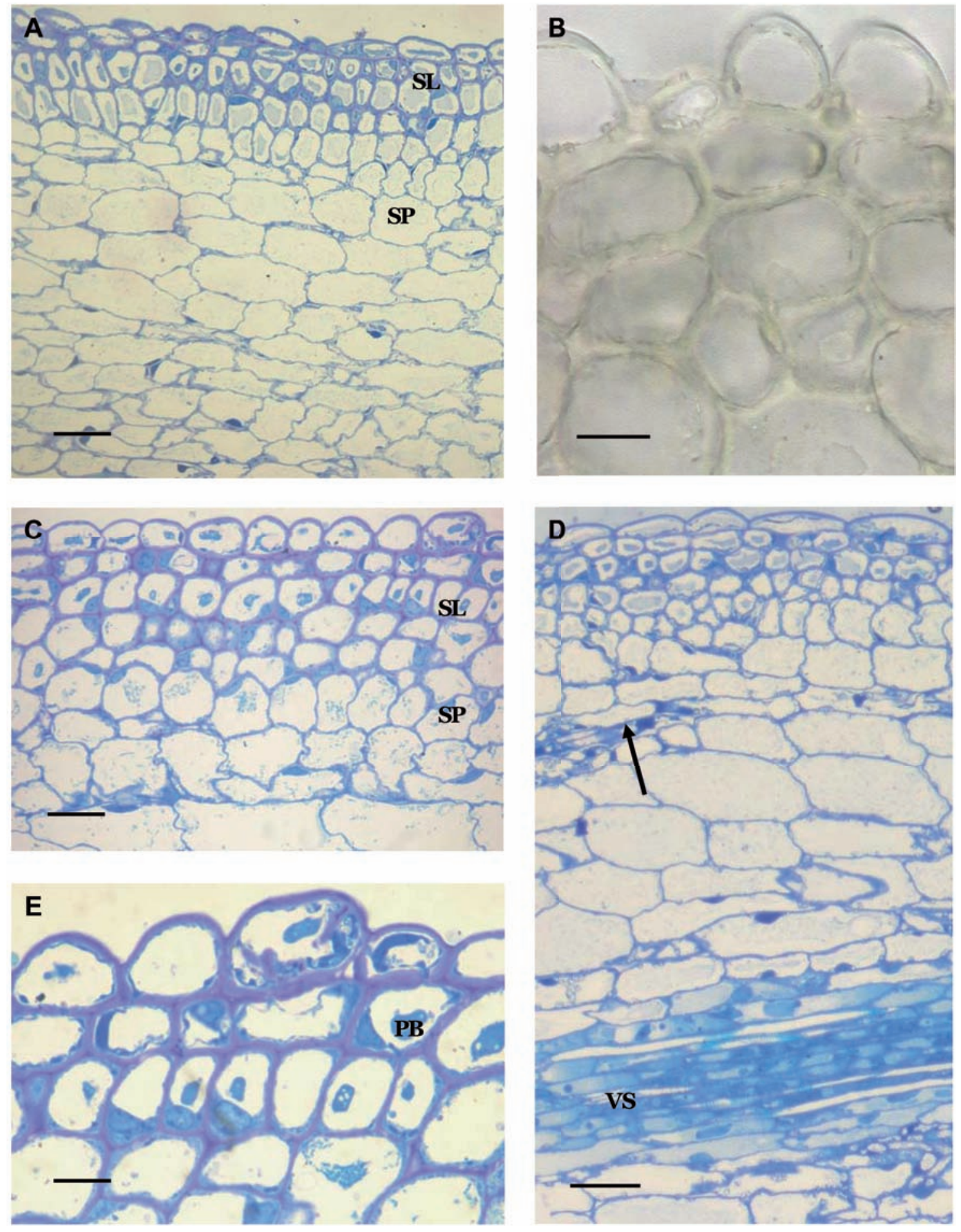

Figs 3A-E. Section (A) through nectary of $O$. sophronitis showing collenchymatous, secretory layer and subsecretory parenchyma. (B) Hand-cut section through secretory layer after treatment with IKI. Note absence of starch. (C) Section showing detail of subsecretory parenchyma with intravacuolar, flocculent material. A similar section (D) showing vascular supply to nectary and phloem strands (arrow) directly beneath the subsecretory parenchyma. (E) Detail of collenchymatous, secretory layer showing thick walls and intravacuolar protein bodies. Scale bars $=50,20,40,50,25 \mu \mathrm{m}$, respectively. 

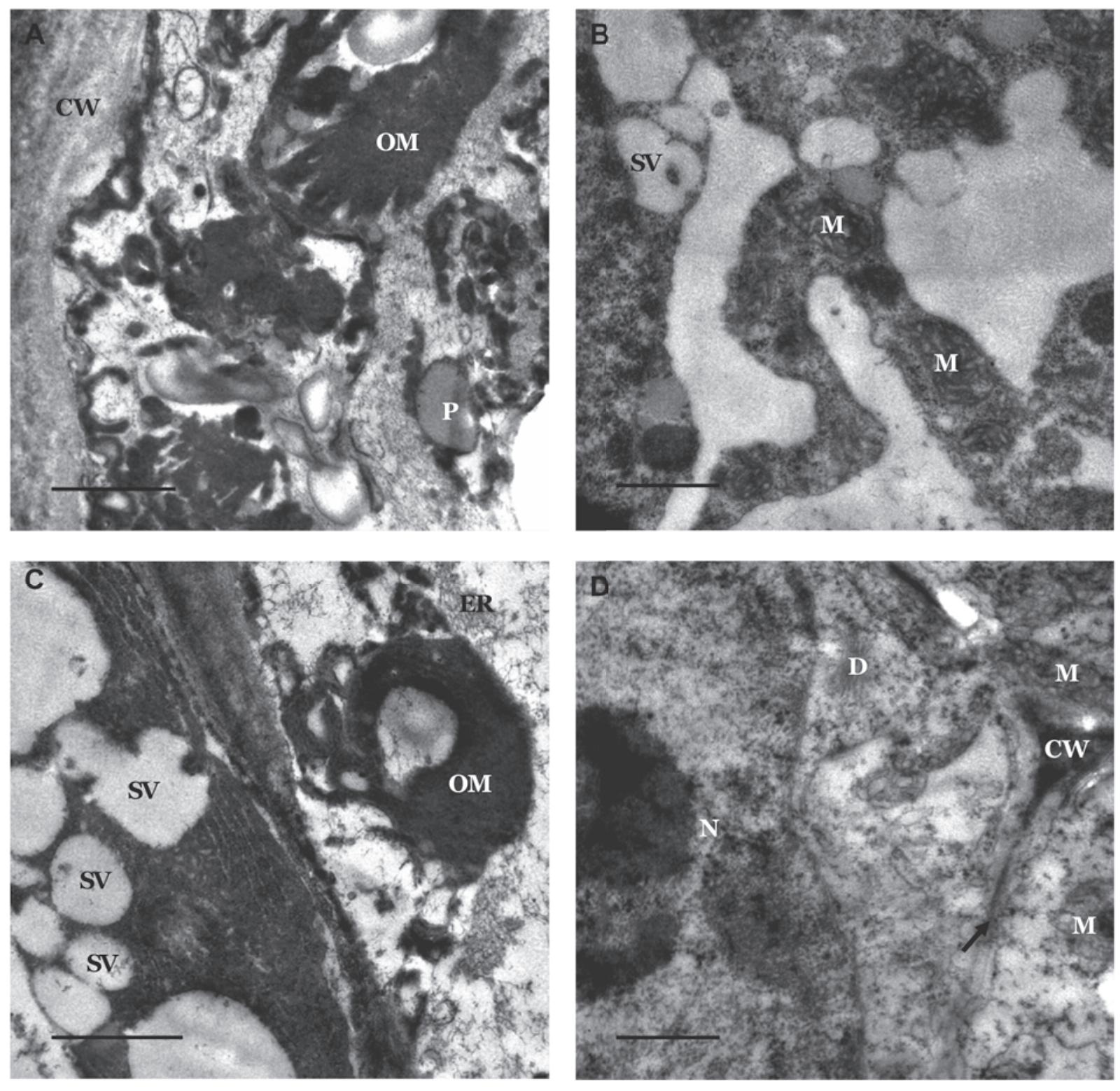

Figs 4A-D. TEM studies of $O$. sophronitis. (A) Section showing outer cell wall and dense cytoplasm containing darkly stained osmiophilic material. (B) Cytoplasm containing mitochondria and secretory vesicles. (C) A similar section to (A) with osmiophilic material, endoplasmic reticulum profiles and pit in cell wall. Note that secretory vesicles aggregate close to cell wall. (D) Section showing nucleus, mitochondria and dictyosomes, as well as plasmodesmata (arrow) in cell wall. Scale bars $=1 \mu \mathrm{m}$, throughout.

Key: $\mathrm{C}=$ cavity $\mathrm{CW}=$ cell wall $\mathrm{D}=$ dictyosome; $\mathrm{ER}=$ endoplasmic reticulum; $\mathrm{L}=$ labellum; $\mathrm{M}=$ mitochondrion; $\mathrm{N}=$ nucleus; $\mathrm{OM}=$ osmiophilic material; $\mathrm{P}=$ plastid; $\mathrm{PB}=$ protein body; $\mathrm{SL}=$ secretory layer; $\mathrm{SP}=$ subsecretory parenchyma; SV = secretory vesicle; VS = vascular strand. 
intravacuolar protein bodies in nectary tissue. Similar protein bodies have occasionally been recorded for both nectary cells (D u rke e, Gall and Re is ner, 1981; Durkee, 1983; Ku o and Pate, 1985) and pseudopollen (Davies, Winters and Turner, 2000). In the latter, protein bodies (probably a storage product) act as a pollinator reward.

Although the nectary cuticle of certain orchids such as Platanthera bifolia (L.) Rich. and P. chlorantha Custer ex Rchb. (S t p i c z y ń s k a, 1997; 2003) is permeable to nectar, in $O$. sophronitis, the cuticle becomes distended due to the pressure formed as nectar is produced and accumulates beneath its surface, resulting in the formation of spherical swellings. These coincide in position with the middle lamella of radial (anticlinal) walls between adjoining epidermal cells. Similar cuticular swellings have also been recorded for other orchid species, such as $O$. coccineum ( $\mathrm{S} \mathrm{t} \mathrm{p}$ i c z y ń s k a et al. 2004) and Hexisea imbricata (S t p i c z y ń s k a et al. 2005), as well as non-orchidaceous taxa, such as $C y$ clanthera pedata Schrad. (N e p i , 2007).

Amyloplasts were absent from the nectary cells of $O$. sophronitis. This is contrary to expectation, as these organelles are often involved in nectar production. Usually, amyloplasts, and the starch grains that they contain, are particularly abundant at the presecretory stage but, as secretory activity progresses, starch disappears and the amyloplasts display irregular profiles (N e p i , 2007). Starchless nectary plastids, similar to those present in $O$. sophronitis, have also been observed for Gymnadenia conopsea (L.) R. Br. (Stpiczyńska and Matusiewicz, 2001) and O. coccinea (S t piczyńs ka et al. 2004) and here, sugars present in nectar are probably delivered in the phloem.

Nectar production is seemingly restricted to only three of the 17 clades recognized by Whitten et al. (2007) as comprising Maxillaria sensu lato, namely Ornithidium, Cryptocentrum Benth. and Camaridium Lindl. However, (W h it te n et al. 2007) were uncertain as to whether nectar is produced by others, such as the Pityphyllum Schltr. and Maxillaria desvauxiana Rchb.f. clades. To date, nectary structure and nectar secretion are known in detail for only two species of Ornithidium (O. coccinea and $O$. sophronitis) and a single species (Maxillaria anceps) currently assigned to the new genus Maxillariella (B 1 a n c o et al. 2007). Nectary structure of both Ornithidium species was very similar and may have evolved in response to similar pollinator pressures. However, these nectaries contrasted greatly with those of $M$. anceps (nectar secreted by labellar callus) and Cryptocentrum (nectary spur; Davies and Stpiczyńska, 2007). Given the enormity of Maxillaria sensu lato and the vegetative and floral diversity of its members, differ- ences in nectary structure are to be expected. Documenting these differences should prove a worthwhile and fruitful field for future research.

\section{Acknowledgments}

K.L.D. is grateful to the Stanley Smith Horticultural Trust (UK) for helping to fund this work. The authors also thank Dr. Michal Rudaś (CLA University of Life Sciences, Lublin, Poland) and Mgr Julita Nowakowska (Laboratory of Electron Microscopy, University of Warsaw, Poland) for use of TEM facilities.

\section{LITERATURE}

Ackerman J. D., 1984. Pollination of tropical and temperate orchids. [In:] K. W. Tan (ed.), Proceedings of the Eleventh World Orchid Conference: 98-101, Miami, Florida: American Orchid Society.

Ackerman J.D., Rodriguez-Robles J. A., Meléndez E. J., 1994. A meagre nectar offering by an epiphytic orchid is better than nothing. Biotropica, 26: 44-49.

Blanco M. A., Carnevali G., Whitten W. M., Singer R. B., Koehler S, Willi a ms N. H., Ojeda I, Neubig K. M., Endara L,. 2007. Generic realignments in Maxillariinae (Orchidaceae). Lankesteriana, 7: 515-537.

Cronk Q., Ojed a I., 2008. Bird-pollinated flowers in a evolutionary and molecular context. J. Exp. Bot. 59 (4): 715-727.

Dafni A., Ivri Y., 1979. Pollination ecology and hybridization between Orchis coriophora L. and O. collina Sot. ex Russ. (Orchidaceae) in Israel. New Phytol. 83: 181-186.

Davies K. L., Stpiczyńska M., 2007. Micromorphology of the labellum and floral spur of Cryptocentrum Benth. and Sepalosaccus Schltr. (Maxillariinae: Orchidaceae). Ann. Bot. 100: 797-805.

Davies K. L., S t pi czy ń ska M., 2008. The anatomical basis of floral, food-reward production in Orchidaceae. In: Texeira da Silva JA(Ed.) Floriculture, Ornamental and Plant Biotechnology V: 392-407. Global Science Books, UK.

Davies K. L., Stpiczyńska M., 2009. Comparative histology of floral elaiophores in the orchids Rudolfiella picta (Schltr.) Hoehne (Maxillariinae sensu lato) and Oncidium ornithorhynchum H.B.K. (Oncidiinae sensu lato). Ann. Bot. 104: 221-234.

Davies K. L., St pi czyńs k a M., Gregg A., 2005. Nectarsecreting floral stomata in Maxillaria anceps Ames \& C. Schweinf. (Orchidaceae). Ann. Bot. 96: 217-227.

Davies K. L., Winters C., Turner M. P., 2000. Pseudopollen: its structure and development in Maxillaria (Orchidaceae) Ann. Bot. 85: 887-895.

Dress le r, R. L., 1971. Dark pollinaria in hummingbird-pollinated orchids or do hummingbirds suffer from strabismus? Amer. Natur. 105: 80-83.

Dressler R. L., 1993. Phylogeny and classification of the orchid family. Cambridge University Press, Cambridge. 
Durke e L. T., 1983. The ultrastructure of floral and extrafloral nectaries. [In:] B. Bentley and T. Elias (eds), The Biology of Nectaries: 1-29, Columbia University Press, New York.

Durkee L. T., Ga11 D. J., Reis ner W. H., 1981. The floral and extrafloral nectaries of Passiflora $\mathrm{L}$. The floral nectary. Amer. J. Bot. 68: 453-462.

Fah n A., 2000. Structure and function of secretory cells. Adv. Bot. Res. 31: 37-75.

Jensen W. A., 1962. Botanical histochemistry: Principle and practice. W. H. Freeman, San Francisco, California, USA.

J o h n s on S. D., B ond W. J., 1997. Evidence for widespread pollen limitation of fruiting success in Cape wildflowers. Oecologia, 109: 530-534.

Johnson S. D., Nilss on L. A., 1999. Pollen carryover, geitonogamy and the evolution of deception in orchids. Ecology, 80: 2607-2619.

Kay Q. O. N., Da oud H. S., Stirton C., 1981. Pigment distribution, light reflection and cell structure in petals. Bot. J. Linn. Soc. 83: 57-84.

Ku o J, Pate J. P., 1985. The extrafloral nectaries of cowpea (Vigna unguiculata (L.) Walp.): I. Morphology, anatomy and fine structure. Planta, 166: 15-27.

Meléndez-Ackerman E. J., Ackerman J. D., Rodriguez-Robles J. A., 2000. Reproduction in an orchid can be resource-limited over its lifetime. Biotropica, 32 : 282-290.

Micheneau C., Fournel J., Pailler T., 2006. Bird pollination in an angraecoid orchid on Reunion Island (Mascarene Archipelago, Indian Ocean). Ann. Bot. 97: 965974.

Neiland M. R. M., Wilc ock C. C., 1998. Fruit set, nectar reward and rarity in the Orchidaceae. Amer. J. Bot. 85: 1657-1671.

Neiland M. R. M., Wilcock C. C., 2000. Effects of pollinator behaviour on pollination of nectarless orchids: floral mimicry and interspecific hybridisation. [In:] K. L. Wilson and D. A. Morrison (eds), Monocots: Systematics and Evolution: 318-326, CSIRO, Melbourne 2000.

Ne pi M., 2007. Nectary structure and ultrastructure. [In:] S. W. Nicolson, M. Nepi, E. Pacini (eds), Nectaries and nectar. Springer, Dordrecht.

Ortega-Olivencia A, Rodriguez-Riano T, Valtuena F. J., Lopez J., Devesa J. A., 2005. First confirmation of a native bird-pollinated plant in Europe. Oikos, 110: 578-590.

Proctor M., Ye o P., 1973. The Pollination of Flowers. Collins, London, UK.

Ruda11 P. J., 2002. Homologies of inferior ovaries and septal nectaries in monocotyledons. Int. J. Plant Sci. 163: 261-276.

Rud all P. J., B ate m an R. M., 2002. Roles of synorganisation, zygomorphy and heterotopy in floral evolution: the gynostemium and labellum of orchids and other lilioid monocots. Biol. Rev. 77: 403-441.
Smets E. F., Decraene L-PR., Caris P, Rudall P. J., 2000. Floral nectaries in Monocotyledons: distribution and evolution. [In:] K. L. Wilson and D. A. Morrison (eds), Monocots: Systematics and Evolution: 30240, CSIRO, Melbourne 2000.

S pecht C. D., 2006. Systematics and evolution of Costaceae (Zingiberales): a multiple dataset approach. Syst. Bot. 31: 89-106.

Stpiczyńska M., 1997. The structure of the nectary of Platanthera bifolia L. (Orchidaceae). Acta Soc. Bot. Pol. 66: 5-11.

Stpiczyńska M., 2003. Nectar resorption in the spur of Platanthera chlorantha (Custer) Rchb. - structural and microautoradiographical studies. Plant Syst. Evol. 238: 119-126.

Stpiczyńska M., Davies K. L., 2006. Nectary structure in Symphyglossum sanguineum (Rchb.f.) Schltr. (Orchidaceae). Acta Agrobot. 59: 7-16.

St piczyńsk a M, D a vies K. L., Gregg, A., 2004. Nectary structure and nectar secretion in Maxillaria coccinea (Jacq.) L.O. Williams ex Hodge (Orchidaceae). Ann. Bot. 93: 87-95.

St piczyńska M., Davies K. L., Gregg A., 2005. Comparative account of nectary structure in Hexisea imbricata (Lindl.) Rchb. f. (Orchidaceae). Ann. Bot. 95: 749-756.

Stpiczyńska M., Matusiewicz J., 2001. Anatomy and ultrastructure of the spur nectary of Gymnadenia conopsea L. (Orchidaceae). Acta Soc. Bot. Pol. 70: $267-$ 272.

van der Cingel N. A., 2001. An atlas of orchid pollination - America, Africa, Asia and Australia. A.A. Balkema, Rotterdam, Netherlands.

van der Pij1 L., Dods on C. H., 1969. Orchid flowers: their pollination and evolution. Coral Gables, Florida: University of Miami Press.

Whitten W. M., Blanco M. A., Williams N. H., Koehler S., Carnevali G., Singer R. B., Endara L, Ne ubig K. M., 2007. Molecular phylogenetics of Maxillaria and related genera (Orchidaceae: Cymbidieae) based on combined molecular data sets. Am. J. Bot. 94: 1860-1889.

\section{Budowa nektarników Ornithidium sophronitis Rchb.f. (Orchidaceae: Maxillariinae)}

\section{Streszczenie}

U większości Orchidaceae występują kwiaty mimetyczne lub zwodnicze, które nie wytwarzają atraktantów pokarmowych. Jednak spora grupa storczyków wabi zapylacze obecnością nektaru kwiatowego. Dotychczas budowa nektarników została zbadana jedynie u dwóch gatunków Maxillaria sensu lato: Maxillaria anceps i Ornithidium coccineum. W niniejszej pracy zostały opisane nektarniki u Ornithidium sophronitis 
(poprzednia nazwa: Maxillaria sophronitis). W kwiatach $O$. sophronitis, podobnie jak u wcześniej badanego $O$. coccineum występuje szereg cech związanych $\mathrm{z}$ ornitofilią, u obydwu gatunków istnieją również liczne analogie w budowie nektarnika. Nektarnik O. sophronitis ma postać zgrubienia na brzusznej stronie kolumny. Wydzielony nektar zbiera się w zbiorniczku utworzonym pomiędzy podstawą kolumny i listków okwiatu. Nektarnik zbudowany jest z epidermy i 3-5 warstw małych, subepidermalnych, kolenchymatycznych komórek sekrecyjnych. Poniżej znajdują się 2-3 warstwy większych komórek miękiszu subsekrecyjnego. W warstwie tej przebiegają pasma floemu. W wakuolach komórek wydzielniczych występuje osmofilny materiał i ciała białkowe, a kutykula pokrywająca komórki epidermy nektarnika uwypukla się pod wpływem nagromadzonego nektaru. Komórki miękiszu położonego pod warstwą sekrecyjną mają cienkie celulozowe ściany i zawierają kłaczkowate osady w wakuoli, przypuszczalnie związane z obecnością flawonoidów.

Podobieństwo budowy kwiatu i mikromorfologii nektarnika $O$. sophronitis do blisko spokrewnionego gatunku Ornithidium coccineum wskazuje na to, że gatunki te ewoluowały w podobny sposób ze względu na podobną presję zapylaczy. 